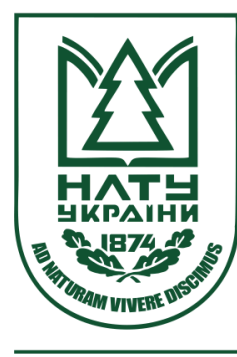

Науковий вісник НЛТУ України Scientific Bulletin of UNFU

http://nv.nltu.edu.ua

https://doi.org/10.15421/40290710

$@ \bowtie$ Correspondence author

Article received 05.09.2019 p.

Article accepted 26.09.2019 p.

S. S. Kurka

УДК 582.471:712

svetlana9075@ukr.net

Уманський наџฺіональний університет садівництва, м. Умань, Украӥна

\title{
ОСОБЛИВОСТІ ВИРОЩУВАННЯ SOPHORA JAPONICA L. У САДОВО-ПАРКОВИХ ГОСПОДАРСТВАХ
}

\begin{abstract}
Наведено узагальнені результати літературного огляду інтродукції і використання в Україні Sophora japonica L. Оцінено перспективність та успішність інтродукції Правобережному Лісостепу та Степу України. Досліджено успішність інтродукціï Sophora japonica L. в умовах Правобережного Лісостепу і Степу України методом інтегральної числової оцінки життєздатності та перспективності інтродукції дерев на підставі візуальних спостережень, який враховує найважливіші для інтродукції показники: ступінь визрівання пагонів, зимостійкість, збереження габітусу, пагоноутворювальна здатність, регулярність приросту пагонів, здатність до генеративного розвитку. Визначено ступінь акліматизації інтродукованого виду Sophora japonica L. методом встановлення акліматизаційного числа. Досліджено декоративність рослин Sophora japonica L. в умовах Правобережного Лісостепу і Степу України. Оцінено декоративність та запропоновано практичні рекомендації щодо перспектив використання Sophora јаponica L. у зеленому будівництві. Відзначено високі адаптаційні можливості виду. Встановлено, що Sophora japonica L. є перспективною рослиною для інтродукції на цій території. Sophora japonica L. не має широкого впровадження в озелененні, оскільки недостатньо повно висвітлено науково обгрунтовані дані з вивчення ії інтродукції в умовах Правобережного Лісостепу України. Тому виникає необхідність виконання роботи, що полягає в узагальненні досвіду інтродукції Sophora japonica L. в цьому регіоні.
\end{abstract}

Ключові слова: Sophora japonica L.; господарське використання; оцінка успішності інтродукції.

Вступ. Впровадження нових, декоративно цінних, рослин у сучасне садово-паркове мистецтво та озеленення вуличних насаджень, які приносять різноманітну користь і мають санітарно-естетичне та культурно-побутове значення є актуальним завданням сучасності. Тому важливу роль у покращенні ландшафтних територій відіграє інтродукція нових деревних і кущових рослин. Останнім часом значно розширився асортимент декоративних рослин, які широко використовують у зеленому будівництві України. Серед них вагоме місце належить виду роду Sophora japonica L. (Yamahara et al., 1990).

Рід Sophora L. належить до переліку груп, які широко використовує людина. Серед його видів можна знайти декілька цінних декоративних рослин. Особливо цікавий китайський вид Sophora japonica L., що культивується у багатьох країнах ще з кінця XVIII ст. У Свропі була інтродукована спочатку у Францію (1747), а потім розповсюджена в інших країнах як декоративна рослина. У Росії вперше з'являється у $1811 \mathrm{p}$. На сьогодні Sophora japonica L. культивується у 82 країнах, особливо широко на Кавказі, в Україні і Середній Азії (Kalinichenko, 2003).

Культивувати Sophora japonica L. в Україні, за одними даними, почали в 1809 р. у Краснокутському дендропарку, за іншими - iї вирощували в Україні вже наприкінці XVII ст. А саме, у розкішному парку шляхтича Скаржинського у цей час з'являється Sophora japonica
(Horoshih \& Horoshih, 1999; Laptev, 2001), доставлена йому морем.

Об'єкт дослідження - біологічні та екологічні особливості Sophora japonica L.

Mета дослідження - виявити, за якими декоративними якостями та біологічними властивостями Sophora japonica L. може бути рекомендована для використання у паркобудівництві та озелененні.

Завдання дослідження - встановити, на підставі біологічних i екологічних особливостей Sophora japonica L., iii придатність до використання у паркобудівництві та озелененні.

Результати дослідження. У Нікітському ботанічному саду Sophora japonica L. почали вирощувати в 1814 р., а вже через 10 років розпочали реалізацію саджанців цієї рослини. У цей же час посадки Sophora japonica L. почали з'являтися в різних куточках України, зокрема у Вінницькій, Львівській, Тернопільській, Одеській, Миколаївській, Херсонській, Харківській, Київській та інших областях. Переважно посадки здійснювали на кладовищах та використовували в озелененні приватних садиб. У Черкаському бору, а в 1895 р. - у Черкаському лісництві (с. Руська Поляна) у шкілках було вирощено 1,7 тис. сіянців Sophora japonica L. першого року і 7 тис. сіянців - другого року.

Висока, пишнокронна, Sophora јаропіса L. дуже нагадує Robinia pseudoacacia, особливо листками, проте вона не має гострих колючок, в неї зеленувата кора,

Інформація про авторів:

Курка Світлана Сергіївна, канд. біол. наук, доцент, кафедра лісового господарства. Email: svetlana9075@ukr.net

Цитування за ДСту: Курка С. С. Особливості вирощування Sophora japonica L. у садово-паркових господарствах. Науковий вісник НЛТУ України. 2019, т. 29, № 7. С. 45-49.

Citation APA: Kurka, S. S. (2019). Some Peculiarities of Coltsfoot Sophora japonica L. Growing in Garden and Park Farms. Scientific Bulletin of UNFU, 29(7), 49-49. https://doi.org/10.15421/40290710

Науковий вісник НЛТУ України, 2019, т. 29, № 7

Scientific Bulletin of UNFU, 2019, vol. 29, no 7 
гладенька 3 темними плямами. Чудові декоративні якості зробили софору рівноправною мешканкою південних міст. Цінністю цього виду в його декоративних властивостях $є$ красиві непарно-перисті світло-зелені листки, що розміщені спірально, завдовжки 2-5 см, які не втрачають блиску навіть у найпосушливіші періоди літа. Листки розпускаються досить пізно - на початку травня. Природній листопад починається у першій половині жовтня, але внаслідок заморозків листки часто осипаються раніше. Sophora japonica L. найвищі декоративні якості проявляє в цвітінні, коли гілки обліплені дрібними густими квітками, які зібрані в суцвіття-китиці завдовжки 30-35 см. Ця рослина є одним 3 найкращих медоносів, оскільки іiі ніжний тонкий аромат приваблює бджіл. Особливо цінним є те, що цвітіння Sophora japonica L. настає пізніше від інших деревних порід - у середині або наприкінці липня і триває до серпня, але строки цвітіння сильно варіюють за роками.
Рослина декоративна також і в плодоношенні своїми оригінальними чітко помітними бобами, що звисають 3 дерева.

Коли відцвітають квітки, на їхньому місці з'являються в'язки бобів - зеленувато-бурі з перетяжками. У середині їх по дві або три насінини, подібні до сочевичних зерняток. Плоди достигають у вересні - жовтні, а іноді і пізніше й можуть триматися на дереві всю зиму (Tucker, 1994).

У 1950-1960 pp. Sophora japonica L. з'являється в Синицькому дендрарії Уманського держлісгоспу, Національному дендрологічному парку "Софіївка", який розташований на північній околиці Умані, що на Черкащині. Водночас Sophora japonica L. широко використовують для створення полезахисних лісових смуг та лісових культур, особливо південних областей України як витривала до посушливого клімату та засоленості грунту порода (Yakovlev, Sytin \& Roskov, 1996).
I

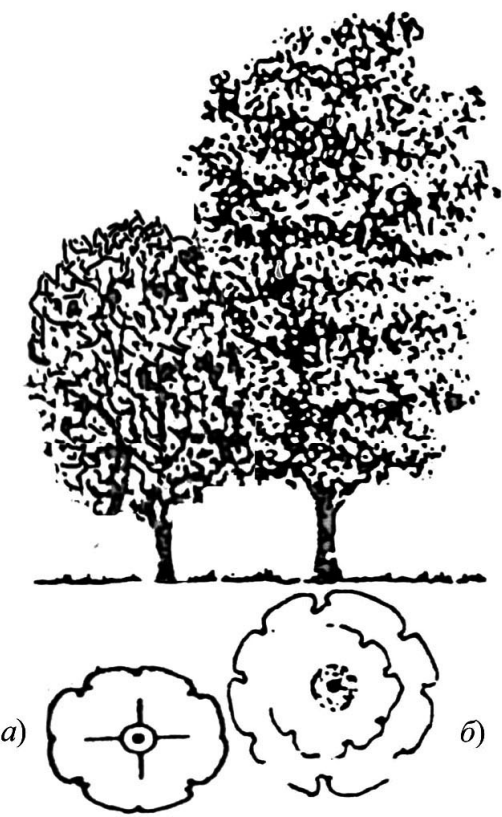

a) Sophora japonica L.,

б) Acer pseudoplatanus L.;

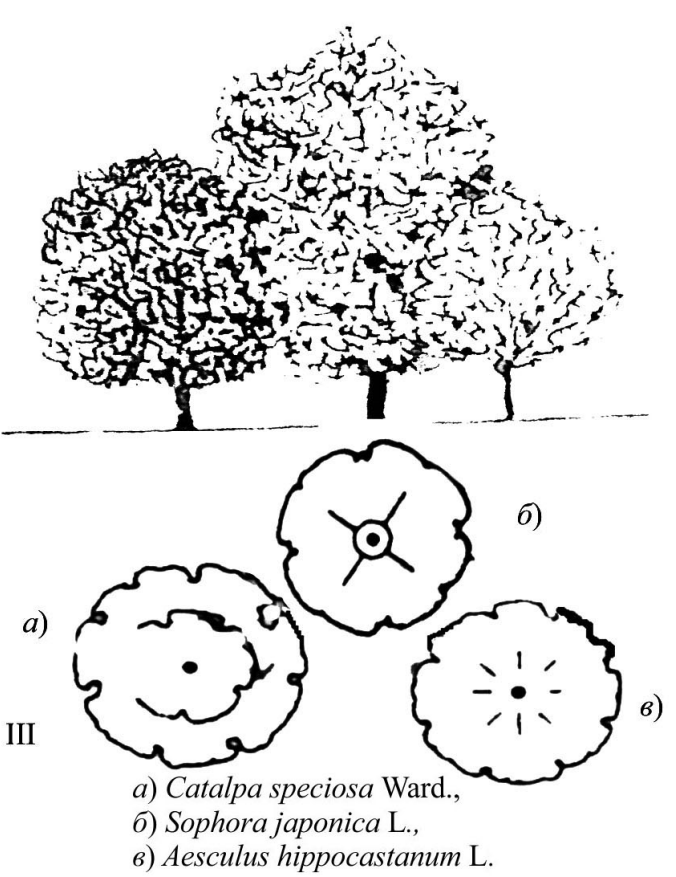

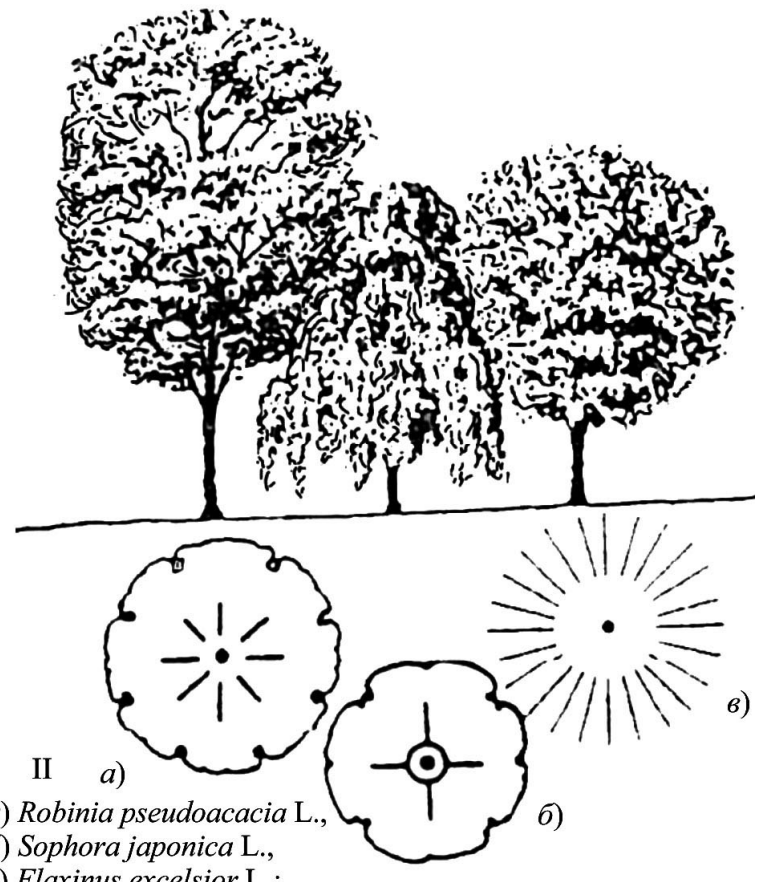

в) Flaxinus excelsior L.,

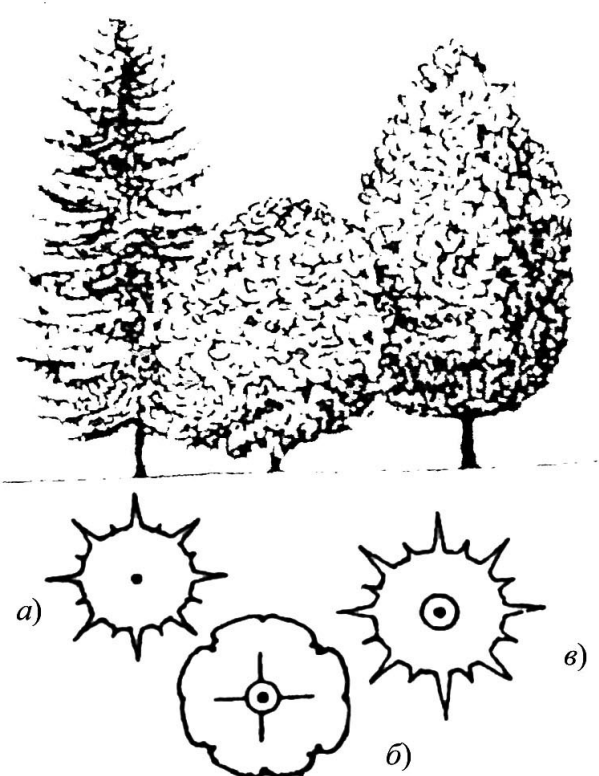

a) Juniperus virginiana L.,

б) Sophora japonica L.,

в) Pinus eldarica Medw.

Рис. 1. Ландшафтні групи з двох, трьох дерев за участі Sophora japonica L. 

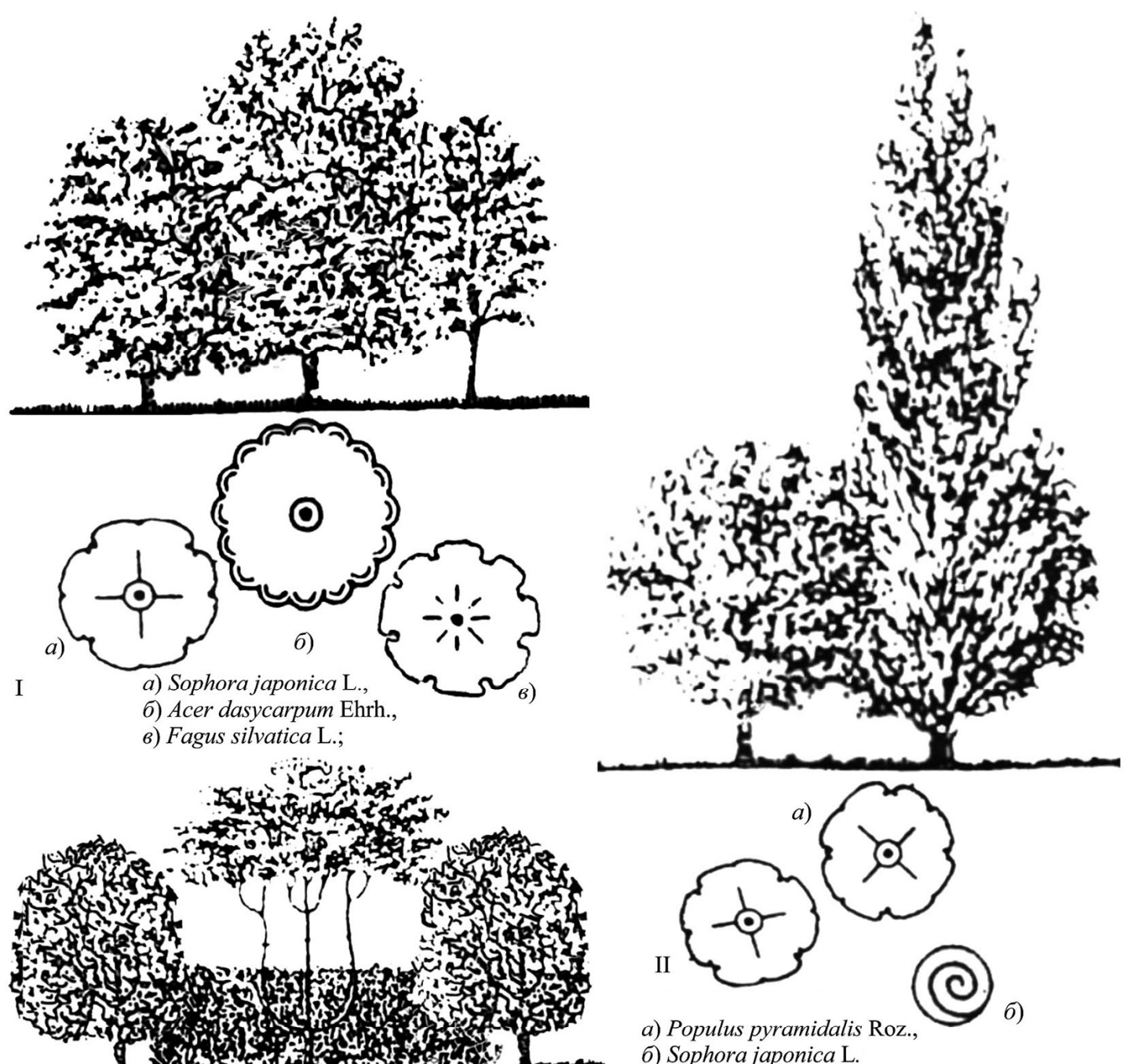

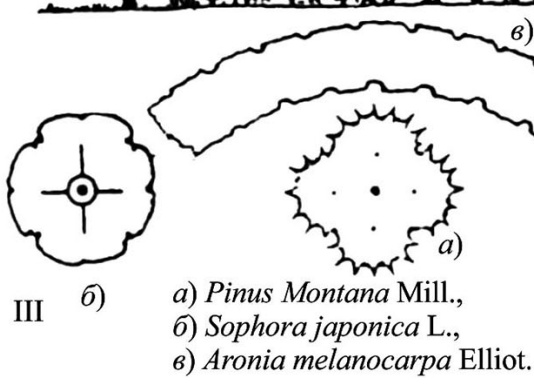

Sophora japonica L. є цінним видом, який можна використовувати в парках, скверах, у вуличних насадженнях. Ми рекомендуємо Sophora japonica використовувати в ландшафтних групах:

- $з$ двох дерев Sophora japonica + клен-явір (Acer pseudoplatanus L.) (рис. 1. II);

- $з$ трьох дерев Sophora japonica + катальпа (Catalpa speciosa Ward.) + каштан кінський (Aesculus hippocastanum L.) (рис. 1. III);

- Sophora japonica + Robinia pseudoacacia L. + ясен звичайний плакучий (Flaxinus excelsiorr L.) (рис. 1, I);

- Sophorajaponica + ялівець віргінський (Juniperus virginiana L.) + сосна ельдарська (Pinus eldarica Medw.) (рис. 1, IV);

- Sophora japonica + клен сріблястий (Acer dasycarpum Ehrh.) + бук лісовий (Fagus silvatica L.) (рис. 2, I);

- регулярними групами - Sophora japonica + сосна гірська (Pinus Montana Mill.) + аронія червоноплідна (Aronia melanocarpa Elliot.) (рис. 2, III), а також Sophora japonica + тополя пірамідальна (Populus pyramidalis Roz.) (рис. 2, II).
На сьогодні в Україні Sophora japonica має широке розповсюдження як цінне паркове дерево для озеленення вуличних насаджень переважної більшості райцентрів України і впевнено приєднується до культурних рослин.

У своїй роботі визначали успішність інтродукції Sophora japonica L. в умовах Національного дендрологічного парку "Софіївка", а також у міських насадженнях Умані та Сміли Черкаської обл. за методом М. А. Кохна (Kohno \& Kurdyuk, 1994). Загальну оцінку інтродукції виводили підсумуванням балів. Найвища оцінка - 100. Залежно від загальної оцінки визначали перспективність інтродукції як дорослих, так і молодих рослин за спеціальною шкалою (табл. 1).

Для оцінювання життєздатності і перспективності інтродукції Sophora japonica L. використали сім основних показників: ступінь щорічного визрівання пагонів, зимостійкість, збереження габітусу рослин, здатність до утворення пагонів, регулярність приросту пагонів, здатність до генеративного розвитку, способи розмноження досліджуваних рослин у районі інтродукції. 
Табл. 1. Шкала оцінки інтродукції деревних рослин за М. А. Кохном

\begin{tabular}{|c|c|c|c|}
\hline \multirow{2}{*}{$\begin{array}{c}\text { Iн- } \\
\text { декс }\end{array}$} & Перспективність & \multicolumn{2}{|c|}{ Сума балів } \\
\cline { 3 - 4 } & інтродукції & $\begin{array}{c}\text { дорослі рос- } \\
\text { лини }\end{array}$ & $\begin{array}{c}\text { молоді } \\
\text { рослини }\end{array}$ \\
\hline I & Досить перспективні & $91-100$ & $56-68$ \\
II & Перспективні & $76-90$ & $46-55$ \\
III & Менш перспективні & $61-75$ & $35-45$ \\
IV & Мало перспективні & $41-60$ & $26-35$ \\
V & Неперспективні & $21-40$ & $16-25$ \\
VI & Цілком не перспективні & $5-20$ & $5-15$ \\
\hline
\end{tabular}

Дослідження проводили впродовж 2016-2019 pp., результати досліджень за сімома основним показниками наведено у табл. 2. Аналізуючи дані цієї таблиці за сумою балів, можна зробити правдоподібний висновок - Sophora japonica L. є достатньо перспективною рослиною для інтродукції в умовах Правобережного Лісостепу та Степу України, ступінь іiі акліматизації у цьому регіоні є добрим, а швидкість акліматизації нормальна, як на наш погляд.

Табл. 2. Оцінка успішності інтродукції Sophora japonica L. впродовж 2016-2019 pp.

\begin{tabular}{|c|c|c|c|c|c|c|}
\hline \multirow[b]{2}{*}{ Показник } & \multicolumn{2}{|c|}{ Дендропарк "Софіївка" } & \multicolumn{2}{|c|}{ м. Умань } & \multicolumn{2}{|c|}{ м. Одеса } \\
\hline & $\begin{array}{c}\text { дорослі росли- } \\
\text { ни, бали } \\
\end{array}$ & $\begin{array}{c}\text { молоді росли- } \\
\text { ни, бали } \\
\end{array}$ & $\begin{array}{c}\text { дорослі росли- } \\
\text { ни, бали }\end{array}$ & $\begin{array}{c}\text { молоді росли- } \\
\text { ни, бали } \\
\end{array}$ & $\begin{array}{c}\text { дорослі росли- } \\
\text { ни, бали }\end{array}$ & $\begin{array}{c}\text { молоді росли- } \\
\text { ни, бали } \\
\end{array}$ \\
\hline $\begin{array}{l}\text { Ступінь щорічного } \\
\text { визрівання }\end{array}$ & 20 & 20 & 20 & 20 & 20 & 20 \\
\hline Зимостійкість & 20 & 15 & 20 & 15 & 25 & 20 \\
\hline Габітус рослин & 10 & 10 & 10 & 10 & 10 & 10 \\
\hline $\begin{array}{l}\text { Пагоноутворююча } \\
\text { здатність }\end{array}$ & 5 & 3 & 5 & 3 & 5 & 3 \\
\hline $\begin{array}{l}\text { Регулярність росту } \\
\text { пагонів }\end{array}$ & 5 & 5 & 5 & 5 & 5 & 5 \\
\hline $\begin{array}{l}\text { Здатність рослин до генера- } \\
\text { тивного розвитку }\end{array}$ & 15 & - & 15 & - & 25 & - \\
\hline $\begin{array}{l}\text { Можливі способи розмно- } \\
\text { ження }\end{array}$ & 1 & 7 & 1 & 7 & 10 & 10 \\
\hline Загальна кількість балів & 76 & 60 & 76 & 60 & 100 & 68 \\
\hline $\begin{array}{l}\text { Перспективність } \\
\text { інтродукції }\end{array}$ & Перспективні & $\begin{array}{c}\text { Досить } \\
\text { перспективні }\end{array}$ & Перспективні & $\begin{array}{c}\text { Досить } \\
\text { перспективні }\end{array}$ & $\begin{array}{c}\text { Досить } \\
\text { перспективні }\end{array}$ & $\begin{array}{c}\text { Досить } \\
\text { перспективні }\end{array}$ \\
\hline
\end{tabular}

Добре росте, плодоносить і за певних умов дає самосів (Одеська, Миколаївська, Херсонська області та Крим). Її поширення на території України досягає широти Києва. Із заходу на схід Sophora japonica L. поширюється, починаючи від Закарпатської обл. (Ботанічний сад Ужгородського Національного університету) і до Дніпропетровської обл. (Ботанічний сад Дніпропетровського Національного університету).

Завдяки декоративним якостям, стійкості до техногенного забруднення в міських умовах та швидкому рості Sophora japonica L. заслуговує ширшого розповсюдження у вигляді солітерів, невеликих груп, що розміщені на передньому плані, в алейних та вуличних насадженнях.

Sophora japonica L. не має широкого впровадження в озелененні, через те, що недостатньо повно висвітлено науково обгрунтовані дані з вивчення іiї інтродукції в умовах Правобережного Лісостепу України. Тому виникає необхідність у виконанні роботи, що полягає в узагальненні досвіду інтродукції Sophora japonica L. в цьому регіоні, визначенні біологічних особливостей росту, розвитку й розмноження. Це дасть змогу розробити заходи щодо ширшого впровадження представників цього виду в культуру та визначити потенційні можливості їі інтродукції в Україні.

Висновки. Sophora japonica L. не має широкого впровадження в озелененні, тому що недостатньо повно висвітлено науково обгрунтовані дані з вивчення іiі інтродукції в умовах Правобережного Лісостепу України. Тому потрібно узагальнити досвід інтродукції Sophora japonica L. в цьому регіоні, визначити біологічні особливості росту, розвитку і розмноження. Це дасть змогу розробити заходи щодо ширшого впровадження пред- ставників цього виду в культуру та визначити потенційні можливості її інтродукції в Україні.

\section{Перелік використаних джерел}

Horoshih, O. G., \& Horoshih, O. V. (1999). Scale of integrated assessment of decorative signs of tree plants. Science Bulletin: Research, Protection and Enrichment of Biodiversity: Scientific Bulletin of UNFU, 9(9). [In Ukrainian].

Kalinichenko, O. A. (2003). Decorative dendrology. Kyiv: Higher School 1990 p. [In Ukrainian].

Kalinichenko, O. A. (2005). Methodical instructions for studying discipline Dendrology. Kyiv: NNK NAU, 46 p. [In Ukrainian].

Kohno, N. A., \& Kurdyuk, A. M. (1994). Theoretical bases and experience of introduction of tree plants in Ukraine, (p. 137). Kyiv: Scientific Opinion, 185 p. [In Ukrainian].

Lapin, P. I. (1967). Seasonal rhythms of the development of tree plants and its importance for introducing. Bulletin of the Main Botanical Garden, (pp. 13-18). Yield, 65 p. [In Ukrainian].

Laptev O. O. (2001). Introduction and acclimatization of plants with the basics of planting greenery. Phytocenter Center ,128 p. [In Ukrainian].

Rusanov, F. N. (1955). Trees and shrubs of the Botanical Garden of the Academy of Sciences of the Uzbek SSR. Tashkent: Publishinghouse of the Academy of Sciences of the UzSSR, 342 p. [In Ukrainian].

Sophora. (1995). The antiulcer action of Sophora and the active constituent in Sophora II. The antiulcer action of vexibinol. Chem. and Pharm. Bull. Vol. 38, № 4, pp. 1039-1044. [In English].

Stirton, C. H. (1981). Petal sculpturing in papilionoid legumes. Advances in legume systematics, 1, 771-788 Kyiv. [In English].

Tucker, S. C. (1994). Floral ontogeny in Sophoreae (Leguinosae: Papilionoideae): II. Sophora sensulato (Sophora group). Amer. J. Bot., Vol. 81, № 3, pp. 368-380. [In English].

Yakovlev, G. P., Sytin, A. K., \& Roskov, Yu. R. (1996). Legumes of Northern Eurasia: A. checklist, Kyiv: Publ. Royal Botan. Gardens, 734 p. [In English]. 


\section{SOME PECULIARITIES OF COLTSFOOT SOPHORA JAPONICA L. GROWING IN GARDEN AND PARK FARMS}

The general results of the literal view of the introduction and usage Sophora japonica L., in Ukraine is presented in the article. The success of the introduction of Sophora japonica L. in the conditions of the Right-bank Forest-steppe and the Ukrainian Steppe is investigated by the method of integral numerical estimation of the viability and perspective of the introduction of trees on the basis of visual observations, and the promise of introduction i.e. by the method considering the most important for introducing indicators such as the degree of maturation of shoots, winter resistance, conservation habitus, spin-forming ability, the regularity of the growth of shoots, the ability to generative development, the way of reproduction in culture. The degree of acclimatization of the introduced species Sophora japonica L. by the acclimatization number by M. A. Kokhna is defined, determining the degree of acclimatization by the value of the acclimation number. The decorative character of Sophora japonica L. plants in the conditions of the Right Bank Forest-steppe and the Ukrainian Steppe is investigated. Perspective and successfulness of introduction in the Right-Bank Foreststeppe and Steppe Belts of Ukraine are weighed up. Decorative characteristics are evaluated. Practical recommendations concerning perspective of application of Sophora japonica L. in landscape architecture are proposed. High adaptation abilities of species in the conditions have been emphasized. We have revealed that Sophora japonica L. is a plant with good prospects for introduction in this region. Sophora japonica L. is not widely used in landscaping due to the lack of full coverage of evidence-based studies of its introduction in the Right-bank Forest Steppe of Ukraine. Therefore, there is a need to perform work that generalizes the experience of introducing Sophora japonica L. in the region, identifying biological features of growth, development and reproduction. This will allow developing measures for wider introduction of representatives of this species into the culture and identifying potential opportunities for its introduction in Ukraine.

Keywords: Sophora japonica L.; economic use; the evaluation of the effectiveness of the introduction. 